\title{
WILLIAMA STERNA INTROCEPCJA WARTOŚCI
}

Gestalte dein Leben so, dass dein Verhalten zu geheiligten Werten in deine eigene Selbstwert-Erfüllung aufgenommen werde. Oder kürzer: introzipiere!

W. Stern

Przedstawienie poglądów W. Sterna na temat introcepcji wartości w niniejszym, dość krótkim artykule nie jest sprawą łatwą. Po pierwsze, nazwisko Sterna, który był twórcą tzw. personalistycznej filozofii wartości, należy raczej do zapomnianych ${ }^{1}$. Po drugie, problem introcepcji wartości pojawia się w całej pełni dopiero w ostatniej, tj. w trzeciej części jego dzieła pt. Wertphilosophie, które z kolei stanowi trzeci tom w dziele zasadniczym Person und Sache. Szczególna trudność wiąże się z punktem drugim. Introcepcja wartości jest bowiem u Sterna ukoronowaniem całego systemu, jego końcowym efektem. Próba spojrzenia na system poprzez pryzmat introcepcji wartości będzie więc z konieczności narażona na niebezpieczeństwo różnych uproszczeń.

Swiadomość powyższych trudności nie powinna nas jednak zniechęcać do podjęcia samego zagadnienia. Zjawisko introcepcji, przyswajania sobie wartości, stanowi przecież jedno z najbardziej doniosłych zagadnień na terenie filozofii wartości. Pytanie o to, czy i w jaki sposób człowiek może docierać do świata wartości; o to, w jaki sposób same te wartości mogą „stawać się ciałem” w naszym życiu, zawsze było pytaniem ze wszech miar interesującym. Wydaje się nawet, że od sposobu odpowiedzi na to pytanie zależała zwykle jakaś zasadnicza życiowa odwaga człowieka lub tej jej brak. Aby zapoznać się ze Sternowską propozycją odpowiedzi na powyższe pytanie, przedstawimy najpierw jego podstawowe stwierdzenie w dziedzinie wartości, następnie opis samego zjawiska introcepcji, na końcu zaś zaprezentujemy przyjmowane przez tego filozofa podstawowe formy introcepcji.

\footnotetext{
* W tekście i przypisach artykulu zastosowano następujący skrót: Wph - W. Stern, Wertphilosophie, Leipzig 1924.

${ }^{1}$ William Louis Stern, ur. 29. 04. 1871 r. w Berlinie, zm. 27. 03. 1938 r. w Durham. Studiował w Berlinie, habilitował się we Wrocławiu, gdzie do r. 1916 był profesorem. Współdziałał przy założeniu uniwersytetu w Hamburgu. Dzięki niemu powstaje tam psychologiczne seminarium i laboratorium. W r. 1933 wyemigrowuje do USA; wykładał Harwardzie i Duke University. Stern należy do wielkich pionierów nowoczesnej psychologii. Jego trzytomowe dzieło: Person und Sache (1906, 1918, 1924) jest wprawdzie, jak mówi szerszy tytuł (System der Philosophischen Weltanschauung) dziełem filozoficznym, tworzy jednak podstawy psychologicznej myśli autora.
} 


\section{PODSTAWOWE STWIERDZENIE W DZIEDZINIE WARTOSCI}

Instancją, której Stern przypisuje nadrzędną rolę zarówno w stosunku do nauki jak i sfery wartości jest metafizyka. Przy czym — zaznaczmy od razu będzie mu chodziło o metafizykę swoiście pojętą; o taką metafizykę, która jest nie tyle nauką o bycie, ile raczej eksplikacją pewnej fundamentalnej wiary, wydobywaniem na światło dzienne pewnego najbardziej pierwotnego przeświadczenia tkwiącego w człowieku. Stern stawia przede wszystkim pytanie o możliwość tak rozumianej metafizyki oraz o uzasadnienie tej możliwości. Jego odpowiedź w tym względzie jest kategoryczna i wyraźna. Pisze: „Czy metafizyka jest możliwa? - Na to bardziej ogólne pytanie należy odpowiedzieć twierdząco: ona jest możliwa, musi być możliwa, ponieważ jest konieczna. Także i nauka jest możliwa tylko wtedy, gdy istnieje metafizyka; i filozofia wartości jest możliwa tylko dzięki temu, że istnieje metafizyka" (Wph 24).

A zatem, jak widać, metafizyka nie tylko jest możliwa. Ona wprost musi być możliwa, ponieważ ,jest konieczna” jako warunek sine qua non nauki i filozofii wartości. Ta bezwzględna konieczność metafizyki jest tutaj jedynym dla niej usprawiedliwieniem. Metafizyka więc, w takim ujęciu, ma prawo do istnienia, ma również swoje znaczenie, chociaż niejako z jej natury wynika, że nie podlega żadnym uzasadnieniom ani dowodzeniom. Metafizyka jest tą dziedziną, która stoi ponad wszelkim uzasadnianiem czy wywodzeniem z czegoś.

Odczytując powyższy tekst Sterna odnosi się wrażenie, że nie sposób uczynić ani jednego sensownego kroku tak na terenie nauki jak i na terenie filozofii wartości, jeśli pominie się próg metafizyki; jeśli wyeliminuje się przyjęcie jakby „na wiarę” - pewnej niezrozumiałej, niemożliwej do wyjaśnienia konieczności. Wrażenie to staje się jeszcze głębsze wtedy, gdy przyjrzymy się podanej przez Sterna definicji owej konieczności metafizyki. Pisze on: „Konieczność metafizyki jest koniecznością pewnej bezpodstawnej wiary oraz koniecznością jakiegoś pierwotnego dążenia w kierunku przedmiotu tej wiary" (Wph 25). Jak się dalej okaże, Sternowi będzie chodziło o wiarę w ostateczną jedność bytu i wartości. Wyzna on, że wierzy w świat, który istnieje i równocześnie ma wartość.

Tkwiące więc w człowieku pierwotne dążenie, skierowuje się na takie określenie bytu, które zawierałoby w sobie element wartości oraz na takie określenie wartości, które byłoby sensem czegoś prawdziwie istniejącego. W ten sposób metafizyka, jej zasadnicza treść, to przede wszystkim wiara poszukująca bytu i wartości. Będzie to wiara, którą charakteryzuje ciągły dynamizm, jako że poszukiwanie bytu i wartości jest poszukiwaniem zawsze aktualnym, nigdy się nie kończącym. Dla człowieka zaś, z taką metafizyczną postawą, świat nie będzie nigdy czymś danym, lecz zawsze czymś zadanym.

Jeżeli chodzi o naukę, nie ma - zdaniem Sterna — dwóch jej rodzajów: dogmatycznej i niedogmatycznej. Istnieje jedynie nauka, która jest świadoma 
lub nieświadoma swoich dogmatycznych podstaw. I to samo, mutatis mutandis, odpowiada dziedzinie wartości. Autor lansuje pogląd, że nie można przypisywać filozofii wartości jakiejś całkowitej samowystarczalności czy autonomii. Uzasadniając pisze: „Wartości bowiem, o których traktuje filozofia, domagają się, wołają o jakiś byt. O tym zaś bycie wie tylko metafizyka. Albo inaczej: ona wierzy w to - nie mogąc ani nie będąc zmuszoną tego dowodzić — że wartości mogą być wartościami tylko dlatego, że żyje w nich jakaś ostateczna realność; że jakieś coś uzyskuje w nich znaczenie i że pragnie się w nich urzeczywistnić coś bytującego" (Wph 29).

Powyższa wypowiedź Sterna dotyczy istnienia wartości; istnienia, którego nie można dowodzić, a które dostępne jest tylko metafizycznej wierze. Nie chodzi tutaj o dokładne określenie sposobu istnienia wartości. Chodzi raczej o ogólne podkreślenie, że przypisywanie wartościom jakiegoś tylko dalekiego i obcego bytowo znaczenia, a więc odmawianie wartościom wszelkiej realności, byłoby nonsensem.

W oparciu o wspomnianą, metafizyczną wiarę jako warunek wszelkiego filozofowania o bycie i o wartości, Stern formułuje zdanie będące jego aksjologicznym a priori: „Wierzę w to, co obiektywnie wartościowe” (Wph 34). Z tego zdania można wyprowadzić podstawowe kategorie aksjologiczne. Mówi ono również o istnieniu koniecznego stosunku pomiędzy podmiotem a przedmiotem: jakieś ja, które wierzy w wartości, które wartościuje, odnosi się do zabarwionych wartościami obiektów, czyli do wartości. Zatem dziedzina badań nad wartościami obejmuje dwie sfery, które muszą być traktowane oddzielnie. $\mathrm{Na}$ terenie każdej z nich aksjologiczne a priori uzyskuje bowiem specyficzną formę: pierwsza dotyczy subiektywnego a priori wartości i wyraża się w zdaniu: wartościuję, więc jestem; druga zaś obiektywnego a priori wartości wyraża się w stwierdzeniu: wartości istnieją.

\section{Subiektywne apriori wartości}

Zdanie „wartościuję, więc jestem” jest świadomie sformułowane na wzór kartezjańskiego „,cogito ergo sum”. Stern pragnie w ten sposób przezwyciężyć intelektualizm jako jedyną podstawę filozofii. Pisze: „Pewność mojego ja nie opiera się ani na myśleniu, na oziębłym konstatowaniu, ani na refleksji nad samym sobą, lecz na zdolności i dążeniu do ustanawiania wartości, do ich uznawania i tworzenia" (Wph 34).

W zacytowanych słowach zawiera się odpowiedź na pytanie, czym jest w swoich najgłębszych pokładach ludzkie ja. Podkreślony jest tutaj ten jego charakterystyczny rys, który sprawia, że do istoty samoświadomości nie należy przede wszystkim refleksyjność, lecz możliwość konstytuowania wartości. Stern - formułując subiektywne a priori wartości na modłę kartezjańskiego 
cogito - odcina się więc radykalnie od Kartezjusza. Jak wiadomo, ego było u tego ostatniego zawsze res cogitans.

Z dalszych wypowiedzi Sterna dowiadujemy się jeszcze czegoś więcej na temat owego rdzenia ludzkiego ja, którym jest wspomniana, przedrefleksyjna samoświadomość. Pisze on: „W akcie wiary w wartości, ja odgranicza się od świata i równocześnie odnosi się do niego. Przyznaje ono samemu sobie sens w jakimś pełnym sensu kosmosie, czyli ustanawia samego siebie. Jego wiara w wartości jest jednocześnie wiarą w wartość samego siebie. - Wartościuję, więc jestem wartością" (Wph 34). Arefleksyjne ja, którego zasadniczą zdolnością jest ustanawianie wartości, uzyskuje więc jeszcze jeden dodatkowy i uzupełniający rys. Przedrefleksyjna samoświadomość jest mianowicie taką samoświadomością, która ma wartość sama w sobie. Takie uzupełnienie subiektywnego a priori wartości umożliwia nam — zdaniem Sterna - uchwycenie kategorii wartości siebie (Selbstwert), jako kategorii domagającej się bezwzględnej wiary. Przede wszystkim jednak dochodzimy do tej subiektywnej wartości siebie, jaką jest osoba, o ile spełnia funkcję wartościowania. Tym bowiem, co według Sterna - nadaje osobie tzw. godność i co sprawia, że jest ona aksjologicznym ja, jest już sama zdolność do funkcji wartościowania w ogóle, a nie dopiero specyficzna, etyczna forma wartościowego zachowania się. To właśnie dzięki funkcji wartościowania w ogóle nasze ja konstytuuje się jako centrum wartości w jakimś wartościowym świecie (por. Wph 35). Oczywiście - co należy jeszcze raz podkreślić — tę zdolność do funkcji wartościowania poprzez wymóg bezwzględnej wiary w wartość siebie.

\section{Obiektywne a priori wartości}

Obiektywne a priori wartości odnosi Stern do ich istoty i istnienia. Czym zatem są wartości i co oznacza tutaj „obiektywne a priori”?

W swoim krótkim opisie fenomenologicznym Stern podkreśla, że w ogóle nie jest możliwe zdefiniowanie pojęcia wartości. Według niego mamy w tym przypadku do czynienia z pojęciem pierwotnym; nie sposób znaleźć jakieś bardziej elementarne pojęcie, do którego można by sprowadzić pojęcie wartości. Próbę jego objaśnienia można jednak podejmować na drodze okrężnej. Wówczas okaże się, że wartość jest przede wszystkim czymś atrybutywnym i niesamodzielnym. Stern powiada, iż „wartość, jako taka, nie jest substancją istniejącą dla siebie, lecz przylega do czegoś (an irgend etwas)” (Wph 41). To „Irgend-Etwas" nazywa nosicielem wartości, przy czym pojęcie to powinno być tutaj rozumiane w sensie możliwie najogólniejszym: jako coś, co w stosunku do wartości posiada charakter substratu, nie domagając się jednak dla siebie absolutnej substancjalności.

Przy opisie wartości należy również — zdaniem Sterna — dokonać pewne- 
go ważnego i koniecznego rozróżnienia. Otóż, wartość zwraca naszą uwagę na znaczenie, pojęcie zaś znaczenia kryje w sobie relację. Pewne A ma znaczenie dla B; dopiero to B nadaje znaczenie A, ono tworzy punkt odniesienia, na który ukierunkowuje się wartościowa własność tegoż A. Każde takie B Stern nazywa celem wartości. I właśnie owe cele wartości odróżnia on wyraźnie od nosicieli wartości. Podkreśla jednak, że same te cele wartości muszą być równocześnie nosicielami wartości.

Dokonując powyższego rozróżnienia, Stern zwraca uwagę na niebezpieczeństwo pojawienia się relatywistycznej teorii wartości, która w swej skrajnej postaci kwestionuje istnienie jakiejkolwiek obiektywności wartości, dostrzegając w nich jedynie „znaczenie dla drugiego"2. Zdaniem Sterna, uniknięcie niebezpieczeństwa relatywizmu jest możliwe wyłącznie na drodze całkowitego utożsamienia nosiciela wartości z jej celem. Wprawdzie wspomniana relacjonalność wartości istnieje nadal, ale nie jest ona już tranzytywna tylko immanentna. Takiemu nosicielowi wartości, który ma znaczenie sam dla siebie, który sam dla siebie jest celem, nadaje Stern miano wartości-samej (Selbstwert). Od razu jednak zaznacza, że istnieją dwa jej rodzaje: wartość-sama, którą musimy przypisać osobowemu ja, jako podmiotowi wartościowania oraz wartośćsama, która przysługuje jakiemuś nie-ja, resp. jakimś nie-ja, jako miejscu pochodzenia obiektywnych stosunków między wartościami.

Od wartości-samych odróżnia Stern inne wartości, które nie posiadają już takiego wsobnego charakteru. Wymienia mianowicie tzw. wartości pochodne (Fremdwerte), wyodrębniając wśród nich dwa podstawowe rodzaje: tzw. wartości-odblaski (Strahlwerte oraz tzw. wartości służebne, względnie rzeczowe (Dienstwerte, Sachwerte).

Wartości-odblaski uzyskują swoją wartość dzięki jakiejś wartości-samej, która jest ich współnosicielem. Np. oko ludzkie czerpie swoją wartość z wartości-samej, jaką jest konkretna osoba. Przy czym stosunek wartości-odblasków do wartości-samej jest więcej niż tylko służebny i rzeczowy. Uwzględniając powyższy przykład, można powiedzieć, że oko jest dla człowieka, jako wartości-samej, czymś o wiele więcej niż mieszkanie czy meble w pokoju.

\section{INTROCEPCJA WARTOŚCI}

Chcąc opisać zjawisko introcepcji, zapytamy najpierw o miejsce jej występowania oraz o jej istotę. Według Sterna, terenem, na którym pojawia się

${ }^{2}$ Co więcej, „to drugie” w obrębie takiej teorii nigdy nie byłoby osiągalne, co Stern wyjaśnia następująco: „Ježeli B jest wartością celową dla nosiciela A, a równocześnie ze swej strony również jest nosicielem wartości, wtedy musi istnieć jakaś dalsza wartość celowa C, od której B otrzymywaloby znaczenie. W ten sposób przesuwanie początkowego punktu idzie w nieskończoność" (Wph 43). 
introcepcja i głównym jej źródłem, jest relacja ja-wartość. Fakt ten uzmysławia nam, dlaczego przywiązywał on tak dużą wagę do subiektywnego i obiektywnego a priori wartości. To podwójne a priori umożliwia właśnie zaistnienie owych relacji ja-wartość; będzie również umożliwiało — jak zobaczymy dalej - samą introcepcję. Przy ustalaniu topografii introcepcji kluczowym stwierdzeniem omawianego autora jest to, że introcepcja dokonuje się zawsze tam i tylko tam, gdzie stają naprzeciwko siebie jakieś osoby. W celu uniknięcia ewentualnego pomieszania pojęć, zwróćmy uwagę na charakterystyczne dla Sterna rozumienie osoby. Wyjaśnijmy też, przynajmniej pobieżnie, jaki jest jej stosunek do naszego ja.

Osoba - w rozumieniu naszego autora — nie jest ani rodzajem jakiejś substancji ani też, tym bardziej, nie jest ona jakąś rzeczą. Jest natomiast pewną kategorią - oprócz kategorii rzeczy — dzięki której, niejako od góry, możemy ujmować znaczenie bytu w jego całości, bezpośredniości oraz w jego specyfice. Stern pisze: „Przez osobę rozumie się coś, co istnieje w taki sposób, że pomimo wielości części tworzy pewną rzeczywistą, odrębną, własnowartościową jedność i co, jako takie, dokonuje jakiejś jednolitej, celowej i samorzutnej działalności" (Wph 66).

Zacytowana definicja przypomina nam wyraźnie określenie wartości-samej, a szczególnie tę jej cechę, którą Stern ujmuje w słowie „In-sich-selbst-Bedeutung-haben". I rzeczywiście autor nasz, formułując obiektywne a priori wartości i analizując istotę wartości-samej, wyraża przekonanie, że „tylko osobom przysługuje wartość-sama" (Wph 65). Zauważmy jednak, iż pojęcie osoby jest tutaj bardzo szerokie, a ponadto, że niekoniecznie musi do niej przynależeć świadomość. Dlatego Stern, od strony czysto formalnej, rozważa możliwość występowania introcepcji również w samym obiektywnym świecie wartości-samych. Ma jednakże świadomość, że pojęcia, którymi się wtedy posługuje są zupełnie puste; że sama introcepcja zamienia się w jakąś myślową jedynie operację. Konieczne jest zatem uwzględnienie odniesienia do ludzkiego ja. O wartościach-samych, jako samodzielnych ośrodkach w świecie wartości, można myśleć wyłącznie hipotetycznie. Natomiast nasze ludzkie ja ustanawiamy zawsze kategorycznie i nieodwołanie jako punkt wyjścia i dojścia wszelkich stosunków pomiędzy wartościami. Z tego też powodu wspomniane wyżej określenie osoby — jako konkretnej, autonomicznej i dynamicznej wielojedni (unitas multiplex) - może mieć zastosowanie przede wszystkim w odniesieniu do naszego ja. Dla człowieka bowiem ów osobowy sposób istnienia jest dostępny — a to dzięki świadomości — w najwyższym stopniu bezpośredniości.

Według Sterna, proces rzeczywistego ustosunkowania się naszego ja do wartości przebiega dialektycznym trójkrokiem. Ogólnie mówiąc, pierwsze dwa kroki — będące jakby tezą i antytezą — tworzą coś w rodzaju przeciwstawnych biegunów. Wynikiem napięcia, jakie się między nimi wytwarza, jest pewna synteza, czyli coś, co Stern nazywa właśnie introcepcją. Najpierw scharak- 
teryzujemy nieco dokładniej pierwsze dwa kroki.

Wymienione kroki oznaczają u naszego autora dwie różne formy zachowania się naszego ja względem wartości. Chodzi mianowicie o dośrodkowe i odśrodkowe zachowanie się, czyli o tendencję do-ja (Ver-Ichung) i tendencję odja (Ent-Ichung). Znamiennym rysem tendencji do-ja jest tzw. Selbstzentrierung, czyli ukierunkowanie na siebie, na własne konkretne ja. To ukierunkowanie jest tendencją do jakiegoś odgrodzenia się od świata, tkwiącą w istocie samej świadomości (por. Wph 206). Oczywiście ów „egocentryzm” należy rozumieć we właściwy sposób. Jest on czymś, co należy do istoty ego w ogóle. Bowiem osoba tylko o tyle jest jakimś ja, o ile wartościując wszystko inne, umieszcza samą siebie w centrum, o ile samą siebie ustanawia wartością-samą. „Egocentryzm” ten nie oznacza, że wszystkie inne wartości są produktem tego ja i że to ja próbuje wynieść ponad nie swoją własną wartość. Stern jest daleki od jakiegoś solipsyzmu czy egoizmu. Ukierunkowanie się ja na samego siebie jest dla niego podstawowym, metafizycznym faktem; jest ponadlogicznym i pralogicznym aktem, którego w żaden sposób nie można już dalej logicznie wyjaśniać ani też z czegoś wyprowadzać. Ponadto, ta zdolność i konieczność skierowywania się ku sobie jest powszechna, dotyczy wszystkich ludzi.

W zachowaniu charakteryzującym się tendencją do-ja, Stern rozróżnia odpowiednio rozumiany subiektywizm i egoizm. Pierwszy ma miejsce w dziedzinie czysto duchowej, drugi - w postępowaniu praktycznym. Subiektywizm jest pewną aksjozoficzną postawą życiową. Dzięki niej dochodzi w nas do głosu osobliwy imperatyw, który kategorycznie domaga się zdania sprawy z wartości samego siebie. Zjawisko subiektywizującej tendencji do-ja jest - i zawsze pozostaje - tendencją ludzkiego ducha; tendencją, która nigdy nie staje się czymś możliwym do przeprowadzenia w sposób absolutny. Dlatego dążność do całkowitego jakby ujedynnienia samego siebie dokonuje się - zdaniem Sterna - li tylko w sferze duchowego eksperymentu. Kiedy zachowanie inspirowane tendencją do-ja z płaszczyzny czysto duchowej przesuwa się na praktyczną, wówczas staje się egoizmem. Nasze ja dąży w tym przypadku do samorzutnego umocnienia i wywyższenia własnej wartości kosztem deprecjonowania innych wartości. Egoistyczne, w powyższym znaczeniu, ale tylko odosobnione akty ja są zrozumiałe. Jako takie, należą bowiem w sposób konieczny do istoty osoby, która — aby móc w ogóle istnieć — musi przynajmniej jakiś wycinek świata posiadać dla siebie jako swoją przestrzeń życiową. Gdyby jednak zachowanie zgodne $\mathrm{z}$ tendencją do-ja przerodziło się w praktycznym życiu osoby w trwały nawyk, wówczas doprowadziłoby ją samą do absurdu i uniemożliwiłoby jej jakikolwiek rozwój.

Krok drugi, czyli zachowanie odśrodkowe i zgodne $\mathrm{z}$ tendencją od-ja jest $\mathrm{z}$ istoty swej podobne do tego, które już omówiliśmy. Różnica polega tylko na odmienności kierunków. Tutaj ja wychodzi, jakby pomija siebie na korzyść świata zewnętrznego. Stern pisze: „Zachowanie podyktowane tendencją od- 
ja polega na takim zachowaniu się ja, w którym jego samodzielna pozycja w świecie oraz znaczenie świata dla owego ja zostają w możliwie najwyższym stopniu wyłączone" (Wph 346). Teraz więc już nie ja jest wartością-samą, ale jest nią jakieś nie-ja. Zachowanie się zgodne z tendencją do-ja — dokonuje się również w dziedzinie czysto duchowej - oznacza proces obiektywizowania. Ma on służyć temu, by - wyłączając poniekąd wartość ja - poznać nie-ja w jego istotowej treści i w jego związkach znaczeniowych. Należy jednak podkreślić, że „obiektywizujące poznanie nie jest zwykłym rejestrowaniem tego, co istnieje i tego, co się dzieje, ale jest selekcją i przetwarzaniem tego, co dane sub specie valoris" (Wph 347). Z zachowaniem się według tendencji od-ja mamy do czynienia przede wszystkim w naukach przyrodniczych (ścisłych). Rzecz jasna, tego rodzaju zachowanie się na ich terenie musi posiadać swoje granice. W przeciwnym wypadku, nauka byłaby ze swej istoty apersonalistyczna, a oczekiwana od niej obiektywizacja byłaby jednoznaczna $\mathrm{z}$ urzeczowieniem. To ostatnie zaś jest dla naszego autora absolutnie nie do przyjęcia. Zdaniem Sterna, obiektywizująca i zgodna $\mathrm{z}$ tendencją od-ja nauka pozostaje jednak zawsze jakąś oceną, a rozpatrywać świat sub specie valoris nie znaczy nic innego, jak rozpatrywać go równocześnie sub specie personalitatis. Dlatego nigdy nie uzna on impersonalizmu jako metodycznej zasady obiektywizującego poznania w ogóle. Stern nie widzi również możliwości, by przy pomocy poznania opartego na tendencji od-ja - zabarwionego zawsze kategoriami osobowymi - uchwycić samą osobę w jej konkretnej istocie. Według niego, takie poznanie osoby jest wprawdzie możliwe, ale dzięki innemu rodzajowi poznania, a mianowicie dzięki tzw. rozumieniu. Do zagadnienia rozumienia będzie jeszcze okazja powrócić na innym miejscu. Tendencja od-ja, podobnie jak tendencja do-ja, może się urzeczywistniać nie tylko na płaszczyźnie teoretycznej, ale również praktycznej. Mamy wówczas do czynienia $\mathrm{z}$ altruizmem, który przejawia się bądź to w postaci służby, bądź to w postaci ofiary. Obiektywna wartość nie-ja zostaje tutaj uznana nie tylko w myśli. Nasze ja oddaje się wręcz na służbę lub też składa $\mathrm{z}$ siebie ofiarę na rzecz konkretnych, innych wartości i celów. I znowu, altruistyczne, oparte na tendencji od-ja akty ja, wypływają — jako akty odosobnione - ze samej istoty osoby. Człowiek bowiem odkrywa w sobie konieczność nieustannego przekraczania własnych granic, jakiegoś wyrastania ponad samego siebie. Z drugiej strony, realizowana praktycznie tendencja od-ja, jako permanentne nastawienie woli, groziłoby człowiekowi jakąś totalną depersonalizacją. Zdaniem Sterna, absolutne urzeczywistnienie tej tendencji nie jest więc w ogóle możliwe do pomyślenia. Nasze ja, nawet jeśli usiłujemy je najbardziej skutecznie wyłączyć jako wartość centralną, pozostaje zawsze ośrodkiem swoich własnych czynów. Np. o żołnierzach i robotnikach mówi się, że peł ni ą swoją służbę. I właśnie ów fakt pełnienia służby odróżnia ich od bezosobowych dział i maszyn, które przy tej ich służbie jedynie funkcjonują. 
Opisane wyżej dwie tendencje nie wyczerpują jeszcze wszystkich możliwych sposobów ustosunkowania się ja do obiektywnego świata wartości. Stern podkreśla, że jeżeli osobowe ja naprawdę zabiega o wzrost, rozwój i kształtowanie siebie jako wartości, to w żadnym razie nie może się ono zadowolić którąś z wymienionych postaw. Bowiem zarówno postawy zgodne $\mathrm{z}$ tendencją doja jak i z tendencją od-ja - gdyby się wyłącznie do nich ograniczyć — prowadzą do groźnego w skutkach niebezpieczeństwa. W przypadku, gdy trwałą cechą osoby staje się tendencja do-ja, zamienia się ona w coś absurdalnego. Dzieje się tak dlatego, że wypierając się wszelkiego innego świata wartości, rezygnując $\mathrm{z}$ jakichkolwiek zobowiązań wobec tego świata, zamyka sobie drogę do bogactwa, jakie tenże świat oferuje. Analogicznie, poprzestanie na samej tylko tendencji od-ja depersonalizuje osobę, zamieniając jej działania wyłącznie we funkcje, w służebność dla samej służebności.

Obie postawy - wynikająca z tendencji do-ja oraz z tendencji od-ja — odnoszą się do osobowego ja. Przyjąć i zaakceptować samego siebie, to po prostu tyle, co zgodzić się z faktem posiadania dwóch nóg; zgodzić się jednocześnie, by przy chodzeniu po drogach świata posługiwać się zarówno nogą lewą jak i prawą. Jednakże zgoda na tę własną, opozycyjną dwutorowość, na ów rozdział i napięcie pomiędzy podmiotem a przedmiotem, które tkwią w samym centrum świadomości jako jej istotny rys, to jeszcze zbyt mało, jeśli chodzi o wymóg pełnego ustosunkowania się osoby względem wartości. Przywodząc na myśl użyte przed chwilą porównanie, można powiedzieć, że z posługiwania się dwoma nogami przy chodzeniu po drogach świata nic jeszcze nie wynika. Można bowiem równocześnie żadnej drogi nie wybierać na serio, a ziemi, po której się stąpa, nie przyznawać w gruncie rzeczy żadnego znaczenia.

Wspomniana opozycja, rozdział i napięcie pomiędzy tendencjami do-ja a tendencjami od-ja, które należą do istoty świadomości, muszą zostać przezwyciężone. I właśnie to przezwyciężenie, które polega na jakimś przetapianiu i zlewaniu się w jedno ja-wartości i nie-ja-wartości, nazywa Stern intocepcją. Pisze: „Introcepcja jest takim zachowaniem się, w którym osoba, usytuowana w centrum jakiegoś świata wartości, afirmuje zarazem swoją własną wartość oraz inne wartości poza sobą" (Wph 88 ).

Powyższe określenie introcepcji znajduje zastosowanie przede wszystkim w odniesieniu do ja ludzkiego, osobowego. Ponadto, takie właśnie jej ujęcie spełnia we filozofii wartości Sterna rolę zupełnie wyjątkową. Odpowiemy więc najpierw na pytanie, dlaczego tak jest, a następnie wyjaśnimy kilka spraw, które - jak się wydaje - pozwolą nam lepiej zrozumieć samo zjawisko introcepcji.

We filozofii Sterna introcepcja ukazuje się jako jedyny możliwy sposób pozytywnego określenia stosunku pomiędzy ja-wartościami a nie-ja-wartościami. Sposób ten polega na tym, że ludzkie ja zachowuje swój subiektywny charakter nie ulegając tendencji do-ja na tyle, by zamienić się w jakąś zamkniętą 
monadę i że jednocześnie uznaje ono obiektywność nie-ja-wartości, nie narażając się - poprzez niewłaściwe urzeczywistnianie tendencji od-ja — na całkowite zatracenie samego siebie. Po prostu z uznanych nie-ja-wartości buduje ono swoją własną wartość. Stern zaznacza nawet, iż w ogóle warunkiem urzeczywistniania przez ludzkie ja swojej własnej wartości jest przyswajanie sobie innych wartości, zamienianie ich na swoją wewnętrzną własność. Dlatego też tam, gdzie będzie chodzić o normy postępowania i o etykę, introcepcja uzyska formę kategorycznego imperatywu, formę jakiegoś powszechnie obowiązującẻgo i ponadczasowego wezwania (Por. Wph 411).

Mówiliśmy już o tym, że ustosunkowanie się ludzkiego ja względem wartości przebiega dialektycznym trójkrokiem. Otóż, pierwsze dwa kroki odnosiły się wprost do świadomości $\mathrm{i}$ - jako że do istoty świadomości należy rozdział i napięcie pomiędzy podmiotem a przedmiotem - znajdowały w niej swoje odbicie. Inaczej przedstawia się sprawa z introcepcją. Będąc syntezą i przezwyciężeniem rozdziału pomiędzy podmiotem a przedmiotem, staje się ona aktem ponadświadomym (por. Wph 354). A zatem introcepcja, chociaż stanowi wynik najsilniejszego przeżycia świadomości, które zmierza do scalenia jakiegoś ja z jakimś nie-ja (tendencje do tzw. Eins-Fühlung i Eins-Denkung), nie mieści się w świadomości. Akt wzajemnego stapiania się ja z nie-ja jest ponadświadomy, posiada w sobie coś z, wybuchających" narodzin. W świadomości znajduje natomiast swój oddźwięk sam efekt introcepcji.

Jest rzeczą wielkiej wagi, by introcipiendum, czyli ten nosiciel wartości, który ma być introcepowany przez jakieś ja, posiadał odpowiedni charakter. Stern pisze: „Aby introcipiendum mogło wejść w pokrewieństwo z wartością-samą ja, musi bądź to od samego początku posiadać charakter osobowy, bądź to uzyskiwać taki charakter w akcie introcepowania. Tylko osoby lub personifikacje mogą być introcepowane" (Wph 353$)^{3}$. Jak widać, introcipiendum musi być zawsze jakąś osobą względnie personifikacją. Uwaga ta pozwoli Sternowi na wyodrębnienie różnych form introcepcji. Z punktu widzenia tak określonego introcipiendum, można mianowicie mówić o takich introcepcjach, które odnoszą się bezpośrednio do realnych osób, o ile one istnieją, istniały lub zaczynają istnieć (introcepcja kochania, rozumienia, działania i tworzenia). Dalej, można się spotkać $\mathrm{z}$ takim rodzajem introcepcji, która zwraca jedynie uwagę na samą osobową doniosłość aksjologiczną introcipiendum, niezależnie od tego, czy tak uposażona osoba istnieje czy nie istnieje realnie (introcepcja symboliczna i estetyczna). I wreszcie, istnieje forma introcepcji, która stanowi jakby połączenie dwóch poprzednich (introcepcja religijna).

\footnotetext{
${ }^{3}$ Według Sterna, metodą ujmowania prawdziwego bytu jest tzw. personifikowanie lub hipostazowanie. Chodzi o to, by pewnej ilości danych nam w doświadczeniu momentów umieć przyporządkować odpowiednią całość bytową i - na odwrót - by z tej całości umieć wydobywać znaczenie poszczególnych elementów (por. Wph 70).
} 
Należy tutaj również podkreślić, iż w zacytowanym powyżej tekście, słowo „pokrewieństwo" nie oznacza w żadnym wypadku równości pomiędzy introcipiendum a wartością-samą ja. Gdyby tak było, wówczas introcepcja nie byłaby ani poszerzeniem ja, ani ubogaceniem wartości introcepowanej. Zdaniem Sterna, pokrewieństwo pomiędzy bytami wartościowymi opiera się na swoistym powiązaniu zgodności i podobieństwa $\mathrm{z}$ innością. Przy takim pokrewieństwie chodzi o współbrzmienie, ale nie w unisono, lecz w akordzie. W nie-ja-wartości, w introcipiendum, osobowe ja pragnie znaleźć coś, co byłoby podobne do niego samego, co byłoby potwierdzeniem i oparciem dla jego własnej wyjątkowości. Równocześnie poszukuje ono tego, czego mu nie dostaje, co mogłoby zapełnić istniejące w nim luki i co niejako zaokrąglałoby jego cząstkowość do jakiejś całości. Analogicznie, również osobowe ja daje i pragnie obdarzać wartości introcepowane tym samym: tym, co stare i nowe oraz tym, co uzupełnia i ubogaca.

Przy opisie zjawiska introcepcji nie można też zapominać o tym, że jest ona dla człowieka stałym, nie kończącym się nigdy procesem. Człowiek, jako istota obdarzona świadomością, nie może się zatrzymywać na żadnej osiągniętej już introcepcji. Pojawiające się w świadomości coraz to nowe antytezy pomiędzy ja-wartościami a nie-ja-wartościami są asumptem do tego, by — w odnawianej wciąż introcepcji - przezwyciężać tendencje do-ja i tendencje od-ja. Przy czym ubogacenie ja-wartości przez jakąś nie-ja-wartość jest w introcepcji czymś nieodwołalnym, niemożliwym do unieważnienia. Granicę introcepcji wyznacza zdolność danego ja osobowego do utożsamiania własnej wartości z wartościami obiektywnymi. Stopień takiej zdolności może być różny, zaś moc introceptywna danego ja musi działać selektywnie i z różną intensywnością otwierać się na dostępne dla niego wartości obiektywne.

W świetle powyższego opisu widać, jak wielką różnorodność sposobów zachowania się względem wartości kryje w sobie introcepcja. Możliwości są tutaj wprost nieograniczone. Na introcepcji też opiera się - i to w swej przeważającej części - faktyczna działalność człowieka.

\section{PODSTAWOWE FORMY INTROCEPCJI}

Ze względu na charakter introcipiendum, Stern wyszczególniał trzy rodzaje introcepcji. W obrębie każdego z tych rodzajów wymieniał następnie formy bardziej podstawowe. Na pierwszym miejscu stawia on te introcepcje, które dotyczą osób realnych. Jako podstawowe formy wylicza tutaj kochanie (das Lieben), rozumienie (das Verstehen), działanie (das Handeln) oraz tworzenie (das Schaffen). Drugi rodzaj introcepcji to introcepcja symboliczna. Stern nazywa ją tak dlatego, że introcepowany nosiciel wartości posiada w tym przypadku osobowość jedynie fikcyjną, jest personifikacją (np. Faust Goethego). 
Podstawową formą tej introcepcji jest estetyczne doznawanie (das ästhetische Geniessen). I wreszcie trzecim rodzajem introcepcji jest introcepcja religijna będąca realistyczną i symboliczną zarazem. Jej formę podstawową stanowi uświęcanie się (das Heiligen). Stosując powyższą kolejność, omówimy poszczególne formy introcepcji ${ }^{4}$.

\section{Kochanie}

Ta forma introcepcji występuje w sposób najbardziej elementarny wszędzie tam, gdzie naprzeciwko ludzkiego ja staje również jakiś realny byt osobowy w ludzkiej postaci. Chodzi o taką sytuację, w której wartość innego ja staje się dla mnie na tyle bliska, że natychmiast jestem pewien wzajemnego z nią pokrewieństwa oraz wzajemnej do siebie przynależności. Doświadczając takiego zbliżenia ludzkie ja zaczyna od razu rozumieć, że jeżeli nadal pozostanie tylko tym, czym było dotąd, wówczas zamieni się w coś absurdalnego, w jakąś zawieszoną w próżni abstrakcję. Dlatego przed ludzkim ja — o ile zdecyduje się ono na pewien exodus, na wychodzenie poza siebie, poza swoją dotychczasową samotność i ograniczoność - otwiera się możliwość osiągnięcia jakiejś nowej, wyższej wartości. W ten sposób początkowe, wczuwające się rozumienie zaczyna przybierać kształt miłości, a bycie razem wyposażonych w wartości podmiotów zamienia się we wspólnotę.

Spotkanie i wzajemne zbliżenie się do siebie dwóch osób może więc zapoczątkować proces, który Stern określił jako realizację tendencji od-ja. Oczywiście, możliwy jest również proces odwrotny, polegający na wstrzymaniu decyzji wychodzenia poza siebie, na pewnym odcinaniu się i odgradzaniu od napotkanej wartości innego ja osobowego. Ale nawet sama nienawiść - jeśli nie jest ona wyłącznie uczuciem niechęci z powodu doznanej od drugiego człowieka krzywdy — posiada jakiś związek z introcepcją. Zdaniem Sterna, zakłada ona bowiem obecność znanego nam już napięcia i ścierania się ze sobą życia dwóch osób. Oba te elementy występują zaś tam, gdzie podejmowana próba introcepcji napotyka na opór ze strony tendencji do-ja.

Rzeczywistych stosunków międzyludzkich nie można nigdy sprowadzać tylko do postaw charakteryzujących się tendencjami do-ja lub tendencjami od-ja. Według Sterna, „warunkiem wszelkich konkretnych stosunków, jakie zachodzą między ludźmi jest introcepcja" (Wph 358). Sądzi on, iż ani powody wyłącznie subiektywne, ani wyłącznie obiektywne nie mogą sprawić, by człowiek kochał drugiego czlowieka. Powód miłowania kogoś - jeśli w ogóle można tak mówić - jest zawsze subiektywno-obiektywny. I tylko taki powód umożli-

${ }^{4} \mathrm{~W}$ swoim fenomenologicznym opisie Stern posługuje się nieco inną kolejnością. Jako kryterium bierze mianowicie rodzaj dziedziny — duchowej względnie praktycznej — na terenie której dokonuje się dana introcepcja. 
wia przerzucenie mostu introcepcji pomiędzy wartością jednej a wartością drugiej osoby. Wyjaśnianie tego, czym jest miłość z pominięciem introcepcji będzie zawsze chybione i niezgodne $\mathrm{z}$ faktycznym stanem rzeczy. Gdyby np. za takie wyjaśnienie uznało się uczucie sympatii, to zaraz po dokładnym przyjrzeniu się temu uczuciu okazałoby się, że nie może ono być wyjaśnieniem wystarczającym. Jako uczucie, posiada ono bowiem zabarwienie zbyt psychologistyczne i wprawdzie może być objawem przenikania się istot oraz wartości, ale nie może stanowić źródła takiego stosunku, jakim jest wspólnota. Nie można zapominać, że sama introcepcja jest procesem ponadświadomym, który w świadomości ma tylko swoje odbicie. Kochających się ludzi łączy ze sobą nie tylko uczucie miłości, które faktycznie w ich świadomości istnieje, ale przede wszystkim łączy ich jakieś realne, wzajemne ubogacenie i rozszerzenie siebie. Gdyby się chciało pozostać przy słowie „sympatia”, to metafizyczne pojęcie introcepcji należałoby raczej porównać do takiego rozumienia sympatii, które było charakterystyczne dla mistycznej nauki o tzw. sympatii wszystkich rzeczy.

Warunkiem prezentowanej tutaj formy introcepcji jest możliwość szczegóInej komunikacji i jednoczenia się ze sobą dwóch różnych, niepowtarzalnych osób. Otóż, owa inność i niepowtarzalność nie może w akcie introcepcji znikać. Stern poddaje krytyce wszystkie te poglądy, które albo te inność i niepowtarzalność ludzkiego ja zbytnio absolutyzują, sprowadzając je do hermetycznie zamkniętej monady, albo nie doceniają tej inności i niepowtarzalności ludzkiego ja poprzez niwelowanie jego odrębności. Jaskrawym przykładem pierwszej skrajności jest twierdzenie Leibniza „omne individuum tota sua entitate individuatur”, przykładem zaś drugiej — indyjska zasada „tat twam asi” ${ }^{5}$. Zdaniem Sterna, nie-ja w stosunku do ja nigdy nie jest czymś totalnie obcym i transcendentnym; można najwyżej powiedzieć, że nie zachodzi między nimi tożsamość. $\mathrm{Z}$ drugiej strony, każde ja, kochając i introcepując inne ja, zawsze zachowuje swoją własną, jedyną i niepowtarzalną istotę - a nawet ubogaca ją dzięki temu, na kogo się otwiera. A właśnie — jak już wiemy — dzięki temu napięciu pomiędzy dwoistością a jednością możliwy jest akt introcepcji.

Introceptywny charakter miłości ujawnia się również przez to, że jest ona zawsze czymś takim, czego nie można ani przemocą wymusić ani też jakoś zaaranżować; ona po prostu „przychodzi i jest” (Wph 359). W tym swoim przychodzeniu i byciu nie jest dla nas zrozumiała. Tkwi w niej jakiś element irracjonalności i cudowności, który do głębi wstrząsa istotą człowieka. Z chwilą, kiedy się pojawia, człowiek sam siebie wprawia w zdumienie. $\mathrm{Z}$ jednej strony nie jest dla niego jasne, dlaczego jakby zniża się i klęka. A z drugiej strony, uczyniwszy już ten gest, pojmuje nagle, że tylko w ten sposób można samymi ustami dotknąć źródlanej wody. Inaczej mówiąc, nie jest oczywiste, że jakaś osoba

5 „Tat twam asi”, czyli „tym jesteś ty”, we filozofii Wedanty oznacza, że u podstaw dostrzegalnej mnogości wszystkich rzeczy leży jakieś identyczne, jedno wspólne ja (tzw. Atman); — por. H. V. Gla s e n p p, Religie niechrześcijańskie, Warszawa 1966, s. 179-180. 
w stosunku do drugiej osoby (lub osób) zachowuje się całkowicie inaczej niż w stosunku do wszystkich innych i że właśnie tylko w tej osobie (lub osobach) przeżywa rozszerzenie, uzupełnienie, wypełnienie, przezwyciężenie własnej ciasnoty oraz własnego egoizmu. Na pytanie, jak to jest możliwe, nie da się w żaden sposób odpowiedzieć. Według Sterna, niemożliwość udzielenia odpowiedzi w tym względzie świadczy tylko o tym, że właśnie personalistyczne ujęcie miłości jest słuszne i najbardziej trafne. Pisze on: „Wszędzie tam, gdzie miłość pojawia się jako wybór i selekcja, nigdy nie zwraca ona uwagi na tę lub inną, pojedynczą cechę osoby, np. na piękną figurę, mądrość, temperament. $\mathrm{W}$ takim bowiem przypadku istniałaby jeszcze jakaś motywacja wyboru. Miłość, tak z jednej jak i z drugiej strony, ujmuje całą osobę w jej niepodzielnej jedyności. A zgadzanie się ze sobą dwóch niepowtarzalnych jedyności da się być może rozumieć, ale nie da się już wyjaśniać ani uzasadniać. „Rozumieć” oznacza tutaj wewnętrzną konieczność wczuwania się, dzięki której te dwie istoty - w tym, co jest w nich podobne - musiały dojść do współbrzmienia oraz - w tym, co w nich zróżnicowane, a nawet przeciwstawne - do wzajemnego uzupełnienia" (Wph 359).

Zlewanie się i współbrzmienie ze sobą dwóch różnych, niepowtarzalnych jedyności stanowi więc kulminacyjny punkt w procesie milości; punkt, który wymyka się wszelkim wyjaśnieniom i uzasadnieniom. Same tylko osoby, które uczestniczą w tym wydarzeniu wiedzą, co się dzieje. Nie umieją jednak nikomu tego wytłumaczyć. Stern, szukając właściwego określenia dla tej decydującej fazy w procesie miłości, odwołuje się do doświadczenia mistyków. Mówi mianowicie o „mistycznej iskrze, która przebiega od jednego do drugiego indywiduum" (Wph 360). Sądzi też, że owa mistyczna iskra jest jednym z najbardziej istotnych elementów w przedstawianej formie introcepcji.

Oprócz tej mistycznej iskry, przebiegającej od jednego do drugiego indywiduum, introcepcję kochania charakteryzuje jeszcze inny, nie mniej ważny moment. Staje się on widoczny wtedy, gdy uwzględnimy miejsce każdego ja w hierarchii osób, gdy to ludzkie ja rozpatrujemy w odniesieniu do ponad-osób (Über-Personen), np. w odniesieniu do rodziny, ojczyzny, ludzkości. W odniesieniach tych również realizuje się introceptywna miłość. Ze względu na swój specyficzny przedmiot, Stern nadaje jej miano miłości abstrakcyjnej, jakby nienaocznej (eine unanschauliche Liebe). $\mathrm{Z}$ powodu swej abstrakcyjności miłość ta może być urzeczywistniana tylko poprzez miłość do jakiegoś konkretnego obok-ja (Neben-Ich). Jeśli więc ktoś kocha drugą osobę, która bezpośrednio jest dla niego uzupełnieniem i wypełnieniem, ten pośrednio kocha równocześnie społeczność, państwo, ludzkość, jako te, których osoba ta jest cząstką i symbolicznym przedstawicielem. W każdej miłości tkwi tego rodzaju dwutorowość. Nie jest ona bowiem wyłącznie związkiem indywiduów, lecz również konkretnym wycinkiem $\mathrm{z}$ jakiegoś ponad-indywiduum.

Ukazana wyżej dwutorowość, podwójne ukierunkowanie - na jakieś 
„obok" i na jakieś „ponad" - stanowi treść drugiego istotnego momentu w introceptywnej miłości. Wszystkie zaś omówione cechy tej miłości pojawiają się również jako istotne rysy w innych rodzajach miłości ${ }^{6}$.

\section{Rozumienie}

Forma introcepcji, którą Stern nazywa rozumieniem, resp. rozumiejącym poznawaniem, zmierza do czysto duchowego ujmowania istoty i wartości jakiejś innej osoby. W porównaniu $\mathrm{z}$ introceptywną miłością, rozumienie charakteryzuje się przewagą strony obiektywnej. Bowiem jedynym celen, który przyświeca rozumiejącemu poznawaniu jest czysto duchowe ujmowanie. Wszelkie tendencje wpływania na introceptywną osobę zostają tutaj wyłączone. Postawa zaś miłości zostaje jakby zredukowana do swobodnego oglądu, który dociera i przenika do najgłębszych pokładów osobowego jestestwa.

W rozumiejącym poznawaniu nie chodzi jednak - jak mogłoby się wydawać - wyłącznie o poznanie wyczerpujące się w tendencji od-ja, lecz przede wszystkim o introcepcję, tzn. o szczególnego rodzaju zjednoczenie się poznającego z poznawanym. Osobowe ja, które dokonuje oglądu może się też z nim realnie identyfikować i niejako kształtować siebie na jego obraz. Introceptywne rozumienie - o ile w ogóle ma się między osobami dokonywać - domaga się istnienia między nimi jakiejś wspólnej płaszczyzny. Wychodzi ono zawsze od tego, co już w jakimś stopniu jest wiadome, co stanowi pewien wspólny horyzont. Według Sterna, taką wspólną płaszczyzną, dzięki której rozumienie dochodzi do skutku, może być wspomniana indyjska zasada „tat twam asi”, byleby jej nie brać w sensie absolutnym.

Omawiana forma introcepcji jest przydatna przede wszystkim w naukach humanistycznych. Te właśnie nauki zajmują się bowiem indywidualnymi istotami jako takimi. Posługiwanie się na terenie tych nauk wyłącznie metodą obiektywizującą, tzn. opartą całkowicie na tendencji od-ja, okazało się szczególnie od czasów Diltheya - błędne i niewystarczające. Stern podkreśla, że wszędzie tam, gdzie chodzi nie tylko o stwierdzania i wyjaśnianie suchych faktów, lecz również o rzeczywiste ujmowanie ich istotowego, niepowtarzalnego znaczenia, pojawia się konieczność uzupełniania poznania obiektywizującego przez rozumienie. Biograf, który zajmuje się Lutrem, czy historyk sztuki, który studiuje wczesny gotyk może z przedmiotu swojego studium utworzyć jakiś indywidualny, żywy i historyczny twór jedynie pod tym warunkiem, że w pewien sposób zjednoczy się z badanym obiektem. W każdym razie, z treścią wartości, którą usiłuje odtworzyć i ożywić musi go łączyć jakieś wewnętrzne pokrewieństwo, coś w rodzaju amor intellectualis. Otóż, tym, co sprawia, że

${ }^{6}$ Autor opisuje jeszcze takie rodzaje introceptywnego kochania jak: miłość rodzinna, erotyczna i społeczna (por. Wph $360-373$ ). 
historyk może niejako sam przeżywać i odtwarzać treść danej wartości są jego własne zdolności do introcepowania. Właśnie przy ich pomocy usiłuje on zrozumieć drugą, introceptywną istotę.

Zdaniem Sterna, bezpośrednim przedmiotem rozumiejącego poznania są historyczne podmioty, czyli prawdziwe osoby, zaś jego przedmiotem pośrednim są tzw. quasi-osoby, czyli różne wydarzenia i procesy historyczne. W pierwszym przypadku, gdy np. mamy do czynienia z jakąś sławną, historyczną osobistością, o jej rozumieniu możemy mówić dopiero po jasnym uchwyceniu sposobu, w jaki próbowała ona urzeczywistniać swoją własną wartość w poszczególnych swych odnoszeniach się do obiektywnej sfery wartości oraz do panującej w owych czasach metafizycznej sytuacji aksjologicznej. Jeżeli zaś chodzi o wydarzenia i procesy historyczne, ich zrozumienie można osiągnąć na dwóch drogach. Pierwsza droga prowadzi poprzez nadanie tym wydarzeniom i procesom historycznym pewnej samodzielności oraz poprzez potraktowanie ich jako quasi-osób. W tych wydarzeniach i procesach historycznych, jako quasi-osobach, zawarta jest bowiem pewna synteza, jakaś struktura wartościowa, którą można już łatwiej uchwycić. Zrozumienie na drodze drugiej polega najpierw na odniesieniu wydarzeń i procesów historycznych do właściwego im podłoża historycznego, a następnie na uchwyceniu ich przynależności do aksjologicznej treści owego podłoża.

Rozumienie jako metoda naukowa nie ogranicza się wyłącznie do dziedziny historii. Stern sądzi, iż jej zastosowanie jest niezbędne nie tylko tam, gdzie przedmiotem badania są jakieś kategorie osobowe. Do tej metody musimy się uciekać również wtedy, gdy tym przedmiotem chcemy uczynić „konkretność osobowej istoty" (Wph 376). Będzie to miało miejsce szczególnie w psychologii przy odnajdywaniu z roz u m i a ł e go obrazu danej osoby, przy poszukiwaniu znacze nia poszczególnych szczegółów w całej strukturze konkretnej, niepowtarzalnej osobowości - znaczenia, które psycholog może niejako sam współprzeżywać introceptywnie.

W przekonaniu Sterna, swoisty charakter introceptywnego rozumienia czyni go podobnym do sztuki. Podobieństwa dopatruje się on we wspólnym obu tym dziedzinom nastawieniu na to, co irracjonalne. Zarówno bowiem w rozumiejącej nauce jak i sztuce chodzi o przedmiot niemożliwy do uchwycenia w kategoriach li tylko obiektywizujących. Ponadto, dostrzega podobieństwo także w jedności postaci nadawanej przedmiotom obu tych dziedzin. Tak w rozumiejącym poznawaniu jak i w sztuce to, co pojedyncze i jednostkowe uzyskuje znaczenie o tyle, o ile przyczynia się do uchwycenia całości w jej własnej strukturze wartościowej. $Z$ tych względów rzeczywistym przedstawicielem rozumiejącej nauki może być tylko ktoś, kto równocześnie — przynajmniej w jakiejś mierze - jest artystą. Wielcy historycy byli zawsze kimś więcej niż tylko sprawozdawcami. Byli oni równocześnie i odtwórcami (Nachgestalter) i twórcami (Neugestalter). W zależności od tego, czy w ich działalności dochodziło do 
głosu pierwsze czy drugie, zaliczano ich bądź do przedstawicieli nauki bądź do przedstawicieli sztuki. Oczywiście bywa i tak, że trudno jest ustalić wyraźną granicę pomiędzy nauką a sztuką. Nie ulega jednak wątpliwości, że jakieś artystyczne, intuicyjne spojrzenie jest niezbędne w obrębie każdej rozumiejącej nauki.

\section{Dziatanie i tworzenie}

Działanie i tworzenie należą do form tzw. praktycznej introcepcji. Chodzi w nich bowiem o równoczesne afirmowanie nie-ja-wartości i ja-wartości, które przejawiałoby się w konkretnych czynach. Stern pisze: „Praktyczna introcepcja to takie działanie, w którym jakieś ja, urzeczywistniając jakieś nie-ja-wartości, realizuje tym samym swoją własną wartość" (Wph 403). Ponieważ to urzeczywistnianie może zmierzać w dwóch kierunkach, stąd dwa jakby podrodzaje praktycznej introcepcji: działanie i tworzenie.

Chcąc uchwycić istotę introceptywnego działania, należy przede wszystkim zwrócić uwagę na ukierunkowanie tego rodzaju aktywności. Otóż, działanie jest zawsze zorientowane na jakąś obiektywną wartość, która jest dana niezależnie od działającego ja. Zdaniem Sterna, celem czynu i działania podejmowanego przez ja ma być urzeczywistnianie tego, co już jest dane jako obiektywna wartość. Ta ostatnia może nam być dana bądź jako sama tylko idea istniejąca w umyśle kogoś drugiego, bądź też w sposób realny w jakimś nosicielu wartości. W pierwszym przypadku wartość trzeba będzie dopiero urzeczywistnić przy pomocy naszego działania, podobnie jak np. murarz wznosi dom według planu, który powstał w głowie budowniczego. W przypadku drugim wystarczy już tylko dbać i troszczyć się o istniejącą wartość, tak jak np. matka dba i troszczy się o dziecko. W każdym razie - zwraca uwagę Stern — działanie staje się tutaj zawsze jakimś środkiem do osiągnięcia celu, który początkowo staje naprzeciwko nas jako coś obcego. Pojawia się nawet pokusa i możliwość działania wyłącznie ze względu na taki czy inny cel. Dla człowieka możliwość taka stanowi zarazem niebezpieczeństwo jego urzeczowienia. Dlatego Stern pisze: „Pewne działanie (ein Wirken) staje się dopiero wówczas 'czynem' (Handlung), gdy jest w nim urzeczywistniany nie tylko obiekt-cel, lecz także i wartość podmiotu tego działania" (Wph 404). Z czynem prawdziwie ludzkim mamy więc do czynienia jedynie wtedy, gdy dana i obca wartość zostaje przez człowieka przemieniona w jego własną wartość oraz przyswojona przez niego od wewnątrz. Ludzkie ja nie może być w swych czynach samym tylko funkcjonującym narzędziem. Jako osoba musi ono być również nastawione na to, by wszelkie dążenia przetwarzać w integralne momenty własnej istoty. Służenie czemuś i samookreślanie siebie zlewają się zatem w jedno, ujawniając tym samym introceptywny charakter czynności ludzkich. Należy podkreślić, że tylko 
w tak rozumianym działaniu widzi Stern gwarancję dla meta-psychofizycznej jedności osoby, a także właściwą podstawę dla etyki personalistycznej.

Przy drugiej formie praktycznej introcepcji nie będzie już chodziło o działanie ze względu na wartości, lecz o uzyskiwanie czegoś z wartości. Zdaniem Sterna, w świecie wartości może się dokonywać prawdziwe tworzenie, tzn. przeprowadzanie $\mathrm{z}$ niebytu $\mathrm{w}$ byt. W sferze wartości obserwujemy ustawiczne powstawanie nosicieli takich wartości, których przedtem w ogóle nie było i które - raz powstawszy — mogą się utrzymywać niezależnie od swego źródła pochodzenia. Otóż, jeśli na gruncie aktywności osobowej mamy do czynienia z nowo powstającymi nosicielami wartości, wtedy Stern mówi o zjawisku ich wytwarzania (Erzeugen). Podkreśla jednak, że o tworzeniu (Schöpfung) par excellence możemy mówić dopiero wówczas, kiedy wytwarzanie to ma charakter introceptywny, tzn. kiedy nasze ja wytwarzające wartość wypełnia ją swoim własnym bytem i - na odwrót - kiedy dzięki wytwarzanej wartości nasze własne ja zostaje obdarzone nowym bogactwem. Introceptywny charakter tworzenia polega tutaj na dziwnej oscylacji, na jakimś „tam i z powrotem”, które dokonuje się pomiędzy twórcą a jego dziełem. Twórca to ktoś, kto jakby zatraca się w swoim dziele, lecz równocześnie żyje w tym dziele nadal, dzieło zaś żyje i działa w nim.

Tworzenie nie różni się w jakiś realny sposób od działania. Stern mówi tutaj jedynic o różnicy pojęciowej. Działanie, które jest zawsze ukierunkowane na już istniejące wartości, wywołuje w nich bowiem zmiany prowadzące do powstania nowych - bardziej lub mniej samodzielnych - tworów aksjologicznych, czyli do jakichś utworów (Schöpfungen). To samo odnosi się również do wszelkiego tworzenia. Skoro domaga się ono, by wartość, która dopiero ma powstać była najpierw dana jako cel dla czynów pośredniczących w osiągnięciu tej wartości, zatem można powiedzieć, że i tworzenie nosi charakter jakichś działań (Handlungen). Różnica pomiędzy działaniem a tworzeniem polega w gruncie rzeczy tylko na tym, że przy pierwszym odniesienie do wartości jest przechodnie, przy drugim zaś nieprzechodnie, immanentne.

Introceptywne tworzenie pojawia się przede wszystkim w dziedzinie twórczości artystycznej. Przy działaniu wartości musiały być już wcześniej dane, a osoba - czyniąc je częścią samej siebie - sprawiała, że przestawały one być czymś obcym oraz istniejącym jedynie na zewnątrz. W twórczości artystycznej nie ma już żadnej uprzedniej obcości, znika również potrzeba jakiegoś powolnego docierania za pośrednictwem czynów do tego, co dane. Sam twórca jest tym, który daje siebie sobie; on sam udziela siebie sobie i światu. Dlatego prawdziwy artysta w najwyższym stopniu upodabnia się do Boga. Posiada on bowiem jakby moc stwarzania. Jego dzieło jest zawsze czymś absolutnie nowym, nigdy dotąd nieistniejącym. Do obiektywnego skarbca wartości dorzuca ono całkowicie nową, oryginalną i niepowtarzalną wartość. $\mathrm{Z}$ tworzeniem jako introcepcją spotykamy się nie tylko przy okazji twórczości artystycznej. Zda- 
niem Sterna, każda codzienna ludzka działalność może mieć w sobie — w większym lub mniejszym stopniu - coś z tego rodzaju introceptywnego zachowania.

\section{Estetyczne doznawanie}

Doznawanie estetyczne jest spośród wszystkich form introcepcji formą najczystszą, tzn. najbardziej autonomiczną i oderwaną od innych sposobów zachowania się względem wartości. Jest to możliwe dzięki specyfice przedmiotów estetycznych, a mianowicie dzięki ich fikcyjności i pozorności. Opisując introceptywne doznawanie estetyczne, Stern zwraca przede wszystkim uwagę na sens oraz rolę fikcji i pozoru w przeżyciu estetycznym. Sądzi on, że fikcyjne i pozorne przedmioty estetyczne posiadają głęboki sens. Posiadają go jednak dopiero wówczas, gdy coś objawiają, gdy o czymś świadczą. Przybliżenie sobie tego sensu staje się możliwe poprzez odnajdywanie znaczenia treści, która jest ujmowana we fikcyjnym przedmiocie estetycznym. O jakie znaczenie może tutaj chodzić? Gdzie tkwią korzenie tego, że człowiek w ogóle o to znaczenie zapytuje?

Stern, odpowiadając na te pytania, powołuje się na aprioryczne, ludzkie pra-credo: „Wierzę w jakiś świat” (Wph 381). Otóż, człowiek jest taką istotą, której nie wystarcza wiara w byle jaki świat. Poszukuje on bytu, który byłby jedynie prawdziwy, jedynie wartościowy. Pragnie zarazem dotrzeć do samego jądra takiego bytu i uczynić go swoim celem. W tych swoich poszukiwaniach i pragnieniach człowiek przeżywa nieustanne rozczarowania. Dzieje się tak zawsze, ilekroć spotyka się on z rzeczywistym, danym mu doświadczalnie światem. Ow świat bowiem jest dla niego często zbyt zawoalowany i tajemniczy. Nie ma w nim nic z tego, czego wiara człowiecza naprawdę poszukuje. Dlatego zwraca się ona ku temu, „co tkwi poza tym wszystkim” (Wph 381). Innymi słowy, czlowiek rezygnuje niejako z realności obiektywnego świata, aby tym bardziej móc być pewnym jego znaczenia. Faust Goethego nigdy nie istniał w rzeczywistości. Istnieje on jednak w jakimś innym sensie, a mianowicie jako symbol, który jest częścią rzeczywistości i który ją w specyficzny sposób odsłania i thumaczy. We fikcyjnym przedmiocie estetycznym chodzi więc o znaczenie, o treść symbolu, poprzez które człowiek odnajduje jedynie prawdziwy, pewny i niezmienny świat, czyniąc go przedmiotem swej wiary. Według Sterna, znaczenie i symboliczność przedmiotu estetycznego nie mogą się stać przedmiotem poznania naukowego. Mogą one być jedynie rozu mi a ne i to wyłącznie poprzez wczuwanie się (Einfühlung).

W przeżyciu estetycznym, ja usiłuje znaleźć potwierdzenie własnej wiary $\mathrm{w}$ to, że wszystko w świecie jest $\mathrm{z}$ nim w jakiś sposób spokrewnione. Jednak wspomniane wyżej rozumiejące wczuwanie się jest możliwe dopiero wówczas, 
gdy to, do czego się odnosi, występuje w postaci jakiejś żywej osoby. Dlatego introcipiendum uzyskuje w przeżyciu estetycznym osobowość, staje się personifikacją. Fakt ten jest oczywisty nie tylko w odniesieniu np. do poezji czy obrazów malarskich mówiących wprost o człowieku. To samo dotyczy również wszystkich innych przedmiotów estetycznych. Np. właściwością namalowanego krajobrazu jest to, że pragnie on objawiać i komunikować swoją wewnętrzną żywotność. Każda dostrzegalna na zewnątrz linia tętni niejako swoim własnym życiem, czyli jest nierozerwalnie związana z drugą, wewnętrzną stroną obrazu, a mianowicie ze znaczeniem. Tak więc, wartość danego nam naocznie obrazu może być wyrażana tylko we formie bytu osobowego. Bowiem jedynie w osobie mamy do czynienia ze ścisłym zespoleniem tego, co zewnętrzne z tym, co wewnętrzne (por. Wph 382). Stąd w estetycznej introcepcji człowiek wychodzi naprzeciwko przedmiotu estetycznego jak do osoby, jak do drugiego ty, personifikuje go przeżywając w nim równocześnie swoją własną jedność oraz zespolenie pierwiastka widzialnego $\mathrm{z}$ niewidzialnym. To osobowe znaczenie, ujmowane przez nas w przedmiotach estetycznych, nazywa Stern bliżej treścią konkretnie idealną (por. Wph 384). Używa on tego określenia dla uwydatnienia faktu, że w przeżyciu estetycznym możliwe jest bezpośrednie, symboliczne ujmowanie idealnego rdzenia różnych osób, czyli ujmowanie, które obywa się bez pojęć. Broni w ten sposób słuszności tzw. konkretnego idealizmu.

Sedno prezentowanej tutaj formy introcepcji polega więc na tym, że dokonuje się ona zawsze pomiędzy osobami, $\mathrm{z}$ których jedna jest realna, a druga symboliczna. Najistotniejsze jednak jest to, że osoby te mogą się ze sobą spotykać introceptywnie, tzn. mogą się ze sobą - oczywiście tylko przejściowo utożsamiać. To utożsamianie się posiada dla ludzkiego ja trwałe znaczenie. Estetyczne współżycie z innymi, symbolicznymi ja daje okazję do wewnętrznego przyswojenia sobie jakiejś cząstki świata, która to cząstka będzie miała odtąd w tym ludzkim ja trwały oddźwięk i szczególne oddziaływanie. Przede wszystkim zaś własny świat wartości owego ja zostanie poszerzony i wzbogacony. A ponieważ w naszym świecie wszystko może się stać przedmiotem przeżycia estetycznego, dlatego w tej formie introcepcji zawarta jest możliwość docierania do wciąż nowych, niezmierzonych bogactw. Zawarta jest w niej również możliwość osiągnięcia najwyższego stopnia introcepcji estetycznej, za który Stern uważa introcepcję wszechosoby. Taki stopień introcepcji polega już na swoistej mistyce, dzięki której uchwytujemy nieskończone piękno wszechświata oraz pokrewieństwo makrokosmicznej wspaniałości z mikrokosmicznym, ludzkim ja. Jednak owa mistyka nie jest jeszcze religią. Zdaniem Sterna, brakuje jej charakterystycznej dla religii tendencji do absolutnego podporządkowania się. Sądzi on natomiast, iż może ona na pewno stanowić jedną z dróg ku prawdziwej religii. 


\section{Introcepcja uświęcająa}

W porównaniu $\mathrm{z}$ wszystkimi innymi formami introcepcji, introcepcja uświęcająca należy do form jakby najbardziej bezwzględnych. Jako introcepcja religijna będzie się ona wznosiła i dotykała samego absolutu. Zarówno w introceptywnej miłości, jak również w introcepcji estetycznej jakieś ponad-ja musiało być projektowane na płaszczyznę ja, musiało mu być przypor zą d k ow y w a ne. I tylko wtedy miłość do konkretnego ty, czy też poznawanie estetyczne, stawały się możliwe. Charakterystycznym rysem opisywanej teraz introcepcji nie będzie przyporządkowywanie, lecz stosunek podporządkowywania. Będzie on dotyczył pewnej wyższej rzeczywistości, która jako nieodparta realność narzuca się ludzkiemu ja. Będzie więc tutaj wchodziło w grę jakieś sacrum, to, co święte. Zdaniem Sterna, sacrum może przybierać różne formy, może być w różny sposób konstytuowane. Zanim przejdziemy do wyszczególniania tych różnych form, poruszymy najpierw zagadnienie istoty tworzenia się tego, co święte w uświęcającej introcepcji.

Jak w każdej introcepcji, tak również i w tej występuje pewna dwoistość. $\mathrm{Z}$ jednej strony, uznanie czegoś za święte jest uznaniem nad sobą jakiejś wyższości, czegoś, co nas określa, co jest dla nas wzorem i co uważamy za doskonałe. Inaczej mówiąc, postawić nad sobą jakąś świętość znaczy uznać tego rodzaju świat wartości, któremu winniśmy posłuszeństwo (Por. Wph 389). Jednak samo to uznanie nie jest jeszcze introcepcją, lecz ujawnieniem się tendencji od$\mathrm{ja}^{7}$. Z introcepcją mamy do czynienia dopiero wówczas, gdy dołączy się element drugi, czyli tendencja do-ja. Jej charakterystycznym rysem jest to, że sacrum, które nas niejako przezwycięża staje się dla nas równocześnie czymś bliskim, czymś, wobec czego nasz stosunek jest już nie tylko za le ż no śc i ą, lecz także przynależnością. Owo „nie tylko, lecz także”, które zawsze towarzyszy temu stosunkowi sprawia, że introceptywne uświęcanie się polega przede wszystkim na zespalaniu tendencji od-ja, czyli na samym podporządkowywaniu się. Dzięki temu, ów stosunek staje się stosunkiem międzyosobowym. Sacrum przybiera wobec ludzkiego ja postać jakiegoś TY. Nie należy jednak zapominać, że to, co święte znajduje się na zupełnie innej płaszczyźnie. Nadal pozostaje ono mianowicie jakimś ponad-ty. Ponadto, ów osobowy rys każdej uświęcającej introcepcji nie zawsze występuje bezpośrednio. Ponad-ty nie jest bowiem czymś naocznie danym.

Stern wyróżnia cztery zasadnicze formy konstytuowania się tego, co święte. Przy czym, pierwsze trzy z nich prowadzą do tzw. religijności partykularnej. Natomiast czwarta, jako oparta na absolutnej introcepcji, uchodzi za źródło religii sensu stricto.

Pierwsza forma konstytuowania się sacrum polega na odpowiednim uzna-

${ }^{7}$ Tendencja od-ja występuje w tym przypadku jako służebność i ofiara (por. Wph 351). 
niu jakiejś osoby, i to bez konieczności jakiegokolwiek pojęciowego, względnie symbolicznego pośrednictwa. Może tutaj chodzić bądź o jakieś konkretne indywiduum, np. o boga-cezara, bądź o jakieś ponad-indywiduum np. gdy wartość tego, co święte utożsamia się z rodziną, narodem lub ludzkością. Nieraz już bywało tak, że atrybuty boskości przypisywano jakiemuś narodowi czy państwu. Ów naród czy państwo stawały się wtedy obiektem religijnej czci i szacunku oraz jedynym źródłem etyki. Podobnie również wielu humanistów absolutyzowało ideał ludzkości. Według Sterna, we wszystkich powyższych przypadkach chodziło wyłącznie o religijność partykularną. Sacrum było w niej czymś wyodrębnianym z nieskończonej hierarchii ponad-osób po to, by jedną z nich ubóstwiać. W efekcie ubóstwiano więc zawsze coś, co może być tylko skończone.

W dwóch następnych formach partykularyzacja ta posuwa się jeszcze dalej. Nie liczą się już tutaj prawdziwe ponad-osoby, lecz tylko pewne twory personoidalne, które - wyizolowane z jakiejś sfery wartości - ulegają personifikacji. Ta personifikacja dokonuje się bądź we formie abstrakcyjnej, pojęciowej, bądź we formie widzialnego symbolu. W pierwszym przypadku charakter $s a$ crum nadawany jest jakimś ideom, którym od Platona po Hegla przypisywano ostateczną, pierwotną bytowość. Osobliwością tej formy konstytuowania się tego, co święte jest duża trudność pojawiająca się przy próbie zharmonizowania pojęciowej abstrakcyjności z właściwą człowiekowi tendencją do ujmowania świętego bytu jako konkretnej osoby. W przypadku drugim powyższa trudność zostaje zniwelowana dzięki wierze w ujmowane symbolicznie siły, które występują w postaci różnych herosów, demonów, proroków i świętych. Zdaniem Sterna, ta forma konstytuowania się sacrum - przynajmniej w pewnym zakresie - pojawia się też w katolicyzmie i buddyzmie. Charakterystyczną cechą posługiwania się tą naiwną i mitologiczną symboliką - która skądinąd posiada całkiem swoistą głębię i znaczenie — jest niezłomna wiara w jej związek z faktycznie istniejącą realnością. Uznanie bowiem tego, co nas przewyższa oraz zaakceptowanie wynikających stąd konsekwencji jest możliwe dopiero wtedy, gdy to coś w sposób niewątpliwy istnieje. Czcić i kochać można wyłącznie takich bogów, którzy rzeczywiście istnieją. Według Sterna, powyższe formy tworzenia się tego, co święte prowadzą zawsze do religijności partykularnej. Sacrum otrzymuje w niej charakter czegoś skończonego i zarazem ograniczonego.

Ostatnia, czwarta forma konstytuowania się tego, co święte, czyli religijność jako tzw. introcepcja absolutna, usiluje przezwyciężyć wspomniany wyżej partykularyzm. Jak w każdej introcepcji, również i w tej będzie miało miejsce przezwyciężanie przeciwieństwa pomiędzy tendencją do-ja a tendencją od-ja. $\mathrm{Z}$ tą jednak różnicą, że to przezwyciężanie będzie się odnosić do przeciwieństw zabsolutyzowanych.

A oto na czym polega każdy z dialektycznych trójkroków w introcepcji reli- 
gijnej par excellence. Krok pierwszy, czyli postawa oparta na tendencji do-ja, zmierza ku temu, by w sposób absolutny oraz całkowicie na serio potraktować własną świętość. Pytania w rodzaju: kim jestem, jaki jestem, po co tutaj jestem, co ze mnie pozostanie, tkwią w centrum każdej religii. Są one stawiane jakby na ostrzu noża, narzucają się z bolesną i zarazem wzniosłą natarczywością. W religii domagają się one również absolutnych odpowiedzi. Dzieje się coś takiego, jakby cały świat zależal od naszego ja. Staje się ono ośrodkiem własnego świata wartości i to nie tylko w granicach swego istnienia. Ono istnieje dopóty, dopóki istnieje jakiś świat, a nawet dłużej. Dogmat mówiący o nieśmiertelności, wiara w wieczne zbawienie lub potępienie, wędrówka dusz - to wszystko stanowi symboliczny obraz tej zabsolutyzowanej ja-wartości.

Następny krok, czyli postawa bazująca na tendencji od-ja, dotyczy zawsze jakiegoś dogmatycznego obrazu świata, który przyjmuje każda religia. Chodzi tutaj o taką czy inną kosmogonię i eschatologię jako naukę o Bogu, doczesności, wieczności, o niebie i piekle. Chodzi tu o szczególnego rodzaju bezwzględną obiektywność, przy poznawaniu której konieczne jest najdalej posunięte wyłączenie własne go ja. Religijne ujęcie świata wychodzi tym razem naprzeciwko człowieka jakc oś tak definitywnego, że nie ma już w jego obrębie miejsca na jakąkolwiek subicktywność, badanie, szukanie, wątpienie czy skrupuły. Taka jest boskość i świat, ludzkie zaś ja może tutaj tylko przyjmować, wierzyć i milczeć (por. Wph 394).

Obydwie zarysowane tendencje nie mogą występować obok siebie w czystej formie. Każda bowiên z nich, na mocy jakiejś wewnętrznej konieczności, nie może się obejść bez pewnych momentów zaczerpniętych z drugiej. Istnieje oczywiście możliwość - jak to nieraz zdarzało się w historii religii — by jedna $\mathrm{z}$ tendencji zaczęła przeważać nad drugą. W pierwszym przypadku doprowadza to do tego, że wszystko — łącznie z Bogiem — zostaje sobie podporządkowane przez ja. W przypadku zaś drugim, ja zostaje zniszczone przez absolut. Dlatego religijność w sensie ścisłym może się pojawić tylko na drodze introcepcji zabsolutyzowanego nie-ja w zabsolutyzowane ja, czyli na drodze wzajemnego zlewania się i jednoczenia obu poprzednich kroków. W wyniku introcepcji, powstaje więc to dziwne, nowe „nie tylko, lecz także”, albo - inaczej — ów stosunek, który jest równocześnie zależnością i przynależnością. Introcepcja religijna uniemożliwia tym samym zarówno samoubóstwienie jak i samounicestwienie $\mathrm{w}$ relacjach pomiędzy ludzkim ja a sacrum. Tzw. zbawienie będzie w tym ujęciu polegało na spełnianiu się naszego ja w absolutnej introcepcji. Natomiast areligijność i grzech będą się pojawiać wszędzie tam, gdzie wysiłek ludzkiego ja koncentruje się wyłącznie na tendencji do-ja.

Dodajmy na koniec, iż Stern za jedynie słuszną uznaje tę religijność, której przedmiotem jest Bóg jako wartość sama w sobie i jako absolutna, wszystko obejmująca oraz wszystko przewyższająca osoba. Bóg, jako taki, jest w swojej istocie nieskończenie święty, a przede wszystkim dostępny człowiekowi na 
drodze introcepcji. Daje ona człowiekowi możliwość scalenia się i jednoczenia z tym absolutnym, osobowym bytem Boga. Tym samym zaś otwiera ona perspektywę nieustannego przyswajania sobie - owego swoistego Eigen-Machen - jedynej i samej Świętości. Przy czym, na całościową postawę człowieka wobec Boga składa się nie tylko introcepcja uświęcająca. Wchodzą tutaj również w grę introceptywna miłość, rozumienie oraz estetyczne doznawanie. Jednak w przypadku tego ostatniego, estetyczny świat pozoru staje się światem absolutnej rzeczywistości.

\section{WILLIAM STERNS INTROZEPTION DER WERTE}

\section{Zusammenfassung}

William Stern (1871-1938), dessen Name heute eher als vergessen gelten kann, war Philosoph und Psychologe in einer Person. Als Philosoph gehört er zu den Schöpfern der sog. personalistischen Wertphilosophie, als Psychologe wird er für einen Bahnbrecher der modernen Experimentalpsychologie gehalten. Im Bereich seines philosophischen Interesses war $u$. a. das Problem der sog. Introzeption der Werte enthalten, d. h. das Phänomen der Aneignung der Werte. Eben die Introzeption stellt seiner Meinung nach den richtigsten Weg zum Wertkosmos dar. Sie allein bewirkt, dass die Beziehung zwischen der.Person als selbstwertigem Zentrum und dem gesamten objektiven Wertkosmos zu einer durchaus positiven Beziehung werden kann. Das menschliche Ich erhält nämlich in der Introzeption einerseits seinen Selbstwert aufrecht, während es denselben andererseits durch Anerkennung einiger Nicht-Ich-Werte bereichert und erweitert. Stern betont, die Fähigkeit, sich andere Werte anzueignen, ja diese zum inneren Eigentum zu machen, sei gar eine Voraussetzung für die Verwirklichung durch das menschliche Ich eines eigenen Wertes. Deshalb werde die Introzeption auf dem Gebiet der Ethik die Rolle eines eigenartigen Imperativs, einer allgemeingültigen und überzeitlichen Aufforderung, erlangen.

Für die Beschreibung des Phänomens von Introzeption benutzt Stern das Schema: These, Antithese und Synthese. Die These wird durch die ständig im Menschen gegenwärtige Tendenz zur Ver-Ichung, die Antithese durch Tendenz zu Ent-Ichung gebildet. Die Synthese, d. h. die Introzeption, besteht in einer eigenartigen Überwindung dieser beiden Tendenzen, wobei die Ich-Werte und die Nicht-Ich-Werte zu einem neuen Ganzen zusammenschmelzen. Eine grosse Bedeutung misst Stern der Tatsache bei, dass die Quelle der Introzeption nur die Relationen Ich-Wert sein können. Diese sind vor allem da vorhanden, wo sich Personen gegenüberstehen. Die Welt subspecie valoris betrachten bedeutet für Stern soviel wie dieselbe sub specie personalitatis betrachten. Er kommt auch zum Schluss, die Introzeption selbst - obwohl sie das Ergebnis eines stärksten Bewusstseinserlebnisses darstellt - sei ein überbewusster Prozess. Die Wirkung der Introzeption gelangt in unser Bewusstsein und findet darin erst ex post ihre Abbildung.

Wegen des unterschiedlichen Charakters des durch das menschliche Ich Introzipierbaren nennt Stern die Grundformen der Introzeption ganz konkret: das Lieben, das verstehende Erkennen, das Handeln und Schaffen, die ästhetische Emphänglichkeit und die heiligende Introzeption. So birgt die Introzeption in sich eine Vielfalt der möglichen Verhaltensweisen gegenüber den Werten. Die Möglichkeit sind hier gar unbeschränkt, so dass die Aktivität des Menschen ganz überwiegend auf der Introzeption beruht. Indem Stern seine Aufmerksamkeit auf dieses erstaunliche Phä- 
nomen konzentriert, will er einen solchen Weg in die uns umgebende Welt weisen, auf dem jene Welt sich gleichsam bereit zeigt, uns ihr geheimnisvolles leben, $d$. h. ihren verborgenen Wert und ihre verborgene Bedeutung mitzuteilen. Das introzeptive Lieben, das verborgene Bedeutung mitzuteilen. Das introzeptive Lieben, das verstehende Erkennen, das Handeln und Schaffen, die ästhetische Empfänglichkeit und die heiligende Introzeption bilden in etwa Stufen auf dem genannten Weg. 